\title{
ПАМ'ЯТІ РЕКТОРА ТЕРНОПІЛЬСЬКОГО ДЕРЖАВНОГО МЕДИЧНОГО УНІВЕРСИТЕТУ ІМЕНІ І. Я. ГОРБАЧЕВСЬКОГО ЧЛЕНА-КОРЕСПОНДЕНТА НАМН УКРАЇНИ, ЗАСЛУЖЕНОГО ДІЯЧА НАУКИ І ТЕХНІКИ УКРАЇНИ, ПРОФЕСОРА ЛЕОНІДА ЯКИМОВИЧА КОВАЛЬЧУКА
}

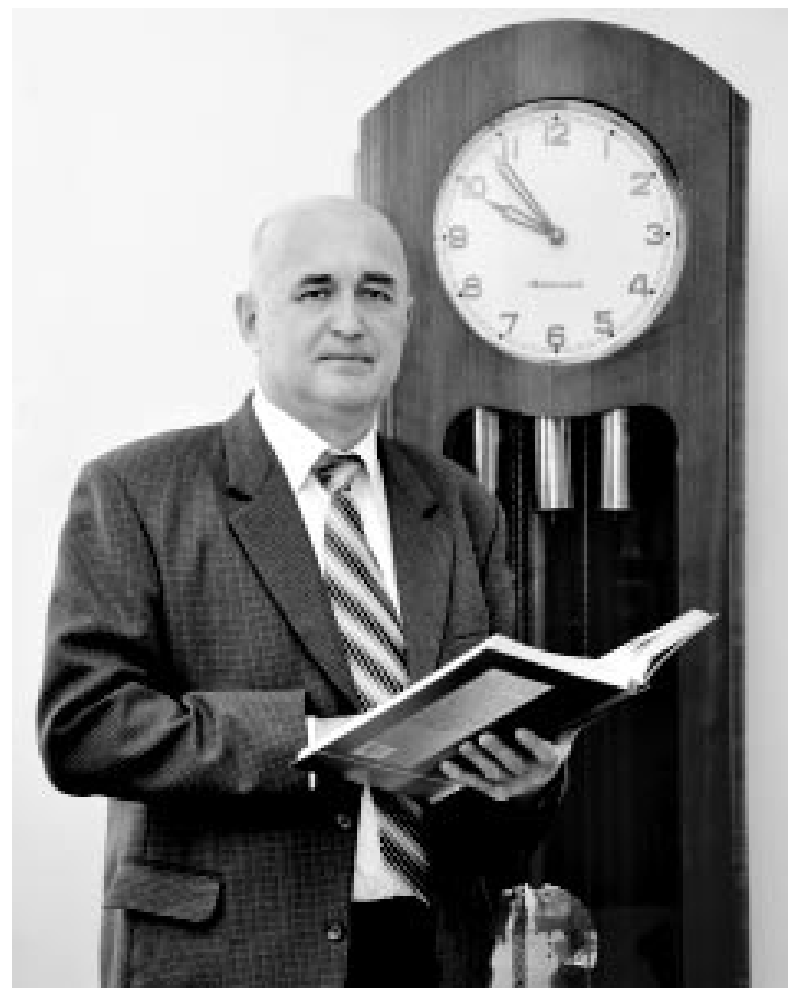

1 жовтня відійшов у вічність ректор ДВНЗ “Тернопільський державний медичний університет імені I. Я. Горбачевського МОЗ України" член-кореспондент НАМН України, заслужений діяч науки і техніки України, доктор медичних наук, професор, заступник головного редактора журналу "Медична освіта" Леонід Якимович Ковальчук.

Професор Л. Я. Ковальчук був одним із провідних учених-хірургів України, очолював Асоціацію хірургів Тернопільщини. Він створив оригінальну наукову школу хірургів, здобутки якої добре відомі в Україні та за її межами. Під його керівництвом захищено 10 докторських і 34 кандидатських дисертації. Він був автором майже 500 наукових і навчально-методичних праць, у т. ч. 8 монографій, 32 винаходів і патентів, 4 атласів оперативних втручань, 6 підручників, 5 навчальних посібників. Зокрема, 2010 р. за його редакцією видано фундаментальний підручник “Хірургія”, який відзначено премією Національної академії медичних наук України.

Наділений вродженим талантом менеджера, Л. Я. Ковальчук проявив новаторський підхід в організації всіх видів діяльності Тернопільської державної медичної академії, яка під його керівництвом отримала статус університету та увійшла в число провідних вищих медичних навчальних закладів України. Крім медичного факультету, його зусиллями відкрито три нові факультети: фармацевтичний, стоматологічний, іноземних студентів; ліцензовано нові спеціальності-“Медико-профілактична справа”, “Біологія”, “Здоров’я людини”. Тепер функціонують шість навчально-наукових інститутів: Інститут морфології; Інститут медикобіологічних проблем; Інститут фармакології, гігієни та медичної біохімії ім. М. П. Скакуна; Інститут моделювання та аналізу патологічних процесів; перший в Україні Навчально-науковий інститут медсестринства; факультет післядипломної освіти реорганізовано в навчально-науковий інститут.

За останні 16 років кардинально зміцнена матеріально-технічна база університету. Комп'ютеризовано всі кафедри, бібліотеку з чотирма читальними залами і філіалами на всіх клінічних кафедрах та в навчально-наукових інститутах, організовано комп’ютерний центр, 46 комп'ютерних класів з виходом до мережі “Інтернет". Створено видавництво "Укрмедкнига" з власним поліграфічним комплексом, яке друкує продукцію лише українською мовою. Видавництво забезпечило підручниками та посібниками вищі медичні навчальні заклади України III-IV рівнів акредитації на $60 \%$, а I-II рівнів акредитації-на 80 \%. Університет є співзасновником і видавцем 12 наукових журналів, випускаються обласні газети "Медична академія" та "Університетська лікарня".

3 ініціативи проф. Л. Я. Ковальчука налагоджена співпраця з 29 іноземними вищими медичними навчальними закладами країн Свропи та Америки. Тільки 2013 року понад 140 викладачів і студентів університету там стажувалися. Відповідно до угоди про співробітництво з Університетом Південної Кароліни Апстейт (Спартанбург, США) у ТДМУ створено умови для навчання в інституті медсестринства (підрозділі університету) американських громадян; уперше серед медичних навчальних закладів запроваджено дистанційне навчання за спеціальнос- 
тями “Сестринська справа-бакалавр”, “Сестринська справа-магістр”. Відбулося вже чотири випуски фахівців. Нині за цією формою навчання здобувають освіту понад 300 іноземних громадян (переважно зі США) та майже 200 українських громадян.

Навчання іноземних студентів розпочато з 1997 року. Тепер в університеті здобувають освіту понад 4500 студентів, у т. ч. понад 1500 іноземних громадян 362 країн світу, понад 90 \% яких навчаються англійською мовою.

За результатами вивчення передового європейського та американського досвіду в Тернопільському державному медичному університеті імені I. Я. Горбачевського запроваджено у навчальний процес низку інноваційних технологій навчання та нових форм організації навчального процесу з урахуванням традицій вітчизняної вищої медичної та фармацевтичної школи й процесу інтеграції національної вищої освіти до європейського освітнього простору: методика “єдиного дня"; циклова система; практично орієнтована Z-система навчання; матрикули практичних навичок; дистанційний контроль знань студентів за програмою “Moodle"; об'єктивно-структурований клінічний іспит (OCKI) та об'єктивно-структурований практичний іспит (ОСПI), семестровий тестовий іспит, який не допускає будь-якого втручання в оцінку знань студентів. Для підготовки висококваліфікованих спеціалістів в університеті функціонують дві програми: "Студентська наука та профорієнтаційне навчання" й “Студент - майбутній фахівець високого рівня кваліфікації"

Активізувалася наукова діяльність. За останні 10 років науковці університету отримали 612 патентів на винаходи. Розроблені в університеті нові методи лікування опіків відзначено Державною премією України в галузі науки і техніки; два науковці стали заслуженими винахідниками України; чотири відзначені премією НАМН України. Захищено 62 докторські і 332 кандидатські дисертації. При університеті працюють 2 спеціалізовані вчені ради із захисту докторських і кандидатських дисертацій з 8 спеціальностей. Щороку на базі конгрес-центру ТДМУ організовують до 30 всеукраїнських і 3 міжнародною участю наукових форумів.

На коопераційних засадах, відповідно до рішення обласної ради та Кабінету Міністрів України, на базі обласної клінічної лікарні з 1 січня 2010 року створена університетська лікарня. Вона має стати найкраще оснащеним спеціалізованим лікувальнопрофілактичним закладом, оскільки, крім фінансу- вання з обласного бюджету, додатково будуть залучені кошти з державного бюджету, а також кошти університету.

У 2010-2012 рр. у п'яти селах області відкрито навчально-практичні центри університету. В найближчих планах - організація центрів "Хоспіс" i “Пункт швидкої медичної допомоги”. Мета створення навчально-практичних центрів: надання медичної допомоги мешканцям села; проходження практики студентами старших курсів медичного факультету та лікарів-інтернів стоматологічного факультету; орієнтація випускників для роботи в сільських медичних закладах.

За підсумками рейтингової оцінки всіх видів діяльності та державного тестування за системою “Крок” Тернопільський медичний університет постійно посідає провідні місця серед вищих медичних навчальних закладів України, а за сумарними показниками 2013 року Міністерство охорони здоров’я України визнало ТДМУ кращим у нашій країні.

Професор Л. Я. Ковальчук був обраний членомкореспондентом Національної академії медичних наук України, удостоєний почесного звання заслуженого діяча науки і техніки України, нагороджений орденом “За заслуги” III ступеня, Почесними грамотами Верховної Ради та Кабінету Міністрів України, Міністерства охорониздоров'я України, найвищою профспілковою нагородою - Почесним знаком Федерації профспілок України “'За розвиток соціального партнерства", визнаний "Людиною року" Тернопілыщини, занесений у Золоту книгу еліти України, удостоєний звань Почесного професора університету Південної Кароліни (США) та Тбіліського державного медуніверситету (Грузія), нагороджений Срібною медаллю Вроцлавського медичного університету (Польща), іменною ювілейною медаллю Братиславського медичного університету (Словаччина).

Л. Я. Ковальчука знали як активного громадського діяча. 32009 року він був депутатом Тернопільської обласної ради, головою комісії з охорони здоров'я, материнства і дитинства, очолював комісію з реформування охорони здоров'я Тернопільщини.

Леонід Якимович Ковальчук був великою та яскравою особистістю, реформатором медичної освіти та охорони здоров'я України, доброю й чуйною людиною. Світла пам'ять про нього назавжди збережеться у наших серцях та в історії рідного університету.

Редакиійна колегія журналу “Медична освіта" 